\title{
MORPHO-PHYSIOLOGICAL AND ANATOMICAL RESPONSES OF WHEAT PLANTS TO MICRONUTRIENTS AND NITROGEN FERTILIZATION \\ Farouk, S. ${ }^{1 *}$; S. E. Seadh ${ }^{2}$; M.I. EL-Abady ${ }^{4}$ and A.M. EL-Ghamry ${ }^{3}$ \\ ${ }^{1}$ Agric. Botany Dept., ${ }^{2}$ Agronomy Dept., ${ }^{3}$ Soil Science Dept., Fac. Agric., Mans. Univ., Mansoura, Egypt \\ 4 Dept. of Seed Technology Res., Field crops Res. Inst., ARC, Giza, Egypt \\ Corresponding Author, Farouk S, gadalla@mans.edu.eg
}

\begin{abstract}
Two field experiments were conducted in 2005/2006 and 2006/2007 in the region of Tag AL-Ezz, Agricultural Research Station Farm, Dakahlia Governorate, Agricultural Research Center, Egypt to evaluate the effect of nitrogen rates and micronutrients fertilizers on wheat plant growth, some physiological and anatomical parameters and yield.

Application of micronutrients combined mixture under high nitrogen rate produced the highest values of plant growth, yield and physiological characteristics compared with other treatments. The second rank best treatment was observed with applications of $\mathrm{Zn}$, then $\mathrm{Mn}$ treatment. $\mathrm{Cu}$ and Fe treatments were equal in its effect and the differences between them were insignificant in the most cases. Application of nitrogen rate up to $90 \mathrm{~kg} / \mathrm{fed}$ increased gradually all studied characters.

Anatomically, application of combined mixtures of micronutrients under high nitrogen rate increased significantly all anatomical characteristics of flag leaf or culm, in particular, number of vascular bundles and thickness of mechanical tissue in culm as well as dimension of vascular bundles, diameter of metaxylem vessels, and thickness of epidermis in both flag leaf and culm. Furthermore, thickness of mesophyll parenchyma and midrib region in flag leaf was also increased.

In conclusion, the obtained results show that foliar application of combined mixture of studied micronutrients ( $\mathrm{Cu}, \mathrm{Mn}, \mathrm{Fe}$ and $\mathrm{Zn}$ ) at the rate of $500 \mathrm{ppm}$ from each under moderate (recommended rate) or high rate of nitrogen fertilizer (70 or 90 $\mathrm{kg} \mathrm{N} / \mathrm{fed}$ ) can be recommended to maximize wheat growth and grain yield per main spike and per plant.

Key words: wheat, micronutrient, nitrogen, culm anatomy, leaf anatomy, growth
\end{abstract}

\section{INTRODUTION}

$\mathrm{Fe}, \mathrm{Mn}, \mathrm{Cu}$ and $\mathrm{Zn}$ are important essential micronutrients for both plant and human. Deficiency of these microelements in human body will result in a series of severe adverse consequences, such as anemia, low immunity function, skin disease, children response slowness and intelligence stunt, and so on. Currently, about one third of world population, in particular, in developing countries, are facing malnutrition problem due to the deficiencies of $\mathrm{Fe} / \mathrm{Zn}$ or vitamin A (WHO, 2007). Traditional nutrient food fortification or medication cannot thoroughly solve this problem due to them only has a temporal role to malnutrition but with expensive costs. However, the micronutrient biofortification of staple food crop is regarded as an effective way to solve this problem (Welch and Graham, 2004). Wheat is a 
staple food crop feeding of the population in Egypt, which also is one of the important approaches for human taking nutrient and microelements from nature. Accordingly, the problem about micronutrient deficiency of human can be solved economically and sustainability by increasing microelements contents in wheat grain and improving their bioavailability. Biofortification, the process of enriching the nutrient content of crops as they grow, provides a sustainable solution to malnutrition in the world (Jeong and Guerinot, 2008). The concept of biofortification is attractive not only for improving the growing conditions of crops but also for exploiting a plant's potential for micronutrient mobilization and utilization. There are several recent reviews on the current strategies for the biofortification of crops, including mineral fertilization, conventional breeding and transgenic approaches (Zhu et al., 2007, Mayer et al., 2008).

During the past three and half decades, micronutrients have occupied an important position in Egyptian Agriculture and have become indispensable to the productivity of crops. Micronutrients have been known to increase the yield and improve the quality of different cereals including wheat (Sienkiewicz-Cholewa, 2008, Seadh et al., 2009). Using soil organic matter leads to a significant and direct impact on the availability of micronutrients as $\mathrm{Zn}$, Fe and Mn (Zhang et al., 2001). However, the soil application of micronutrients fertilizers in the cultivar may not meet the crop requirement for growth and nutrient use, thus the alternative effective approach is to apply these micronutrients as foliar spray (Seadh et al., 2009). Foliar application with differed micronutrients could be equal or more effective the soil applied and used effectively to overcome the problem of micronutrient deficiency in subsoil (Sienkiewicz-Cholewa, 2008).

Rapid increase in wheat consumption outpaced domestic production due to population growth. The area of wheat in Egypt was estimated at about 2841795 fedden in the 2008/2009 season, which produced about 8.000 million tons. Over all agriculture production from wheat has tended to increases increscent years, but even this is not enough to keep up with population growth. Accordingly, there are still many efforts are underway to improve wheat productivity of unit area such as using optimum nitrogen fertilizer level. Nitrogen fertilization is a key input for increasing wheat productivity in Egypt. Although, the introduction of high yielding cultivars has significantly contributed to the prospect of increasing yields, this increase was often associated with intensive cultivation, in which a high level of $\mathrm{N}$ was applied. This high rate of application might negatively affect the agroenvironment through nitrate leaching and ground water pollution. Therefore, it is necessary to improve the management of nitrogen fertilization to maintain the growth and productivity of wheat and develop a more sustainable production system.

Our investigations aim to evaluate the efficiency of micronutrients foliar application on improving wheat growth and yield as well as physiological and anatomical responses under nitrogen fertilizer 


\section{MATERIALS AND METHODS}

Two field experiments were conducted, during the principal 2005/2006 and 2006/2007 seasons at the region of Tag AL-Ezz, Agricultural Research Station Farm, Dakahlia Governorate, Agricultural Research Center, to study the effect of foliar application with micronutrients and nitrogen rates, as well as, their interactions on growth, anatomical and physiological characters as well as grain yield of wheat plant.

The field experiments were laid out in a split-plot design with three replicates. The main plots were allocated to seven foliar treatments as follows: $\mathrm{CuSO}_{4}, \mathrm{Mn}$-EDTA, Fe-EDTA and Zn-EDTA at the rate of $500 \mathrm{ppm}$ of each as well as the combined mixture of these micronutrients together at the rate of $500 \mathrm{ppm}$ of each and water spraying beside control plants (without spraying). The foliar solution was at the rate of 200 liter/fed and spraying was done until saturation point twice at the formerly rate after 30 and 50 days from sowing.

The sub plots were assigned to three nitrogen rates $(50,70$ and 90 $\mathrm{kg} \mathrm{N} / \mathrm{fed})$. The nitrogen fertilizer in the form of urea $(46.5 \% \mathrm{~N})$ was applied as soil addition in two equal doses prior to the first and the second irrigations. Before planting, both physical and chemical analysis for the soil under investigation was undertaken according to Jackson (1973) and corresponding data are presented in Table 1. Each experimental unit was $3 \mathrm{~m} \times 3.5 \mathrm{~m}$ occupying an area of $10.5 \mathrm{~m}^{2}$ (i.e. 1/400 fed). The preceding summer crop was rice (Oryza sativa L.) in both seasons.

Table 1: Physical and chemical soil characteristics at the experimental sites during the growing $2005 / 2006$ and $2006 / 2007$ seasons.

\begin{tabular}{|c|c|c|c|c|c|c|c|c|c|c|}
\hline \multicolumn{11}{|c|}{ Physical characteristics } \\
\hline \begin{tabular}{|l|} 
Properties \\
Seasons \\
\end{tabular} & Soil texture & $\begin{array}{c}\text { Coarse } \\
\text { sand } \\
(\%)\end{array}$ & $\begin{array}{c}\text { Fin } \\
\text { san } \\
(\%\end{array}$ & & $\begin{array}{l}\text { Silt } \\
(\%)\end{array}$ & $\begin{array}{l}\text { Clay } \\
(\%)\end{array}$ & $\mid \begin{array}{c}\mathrm{CaCO}_{3} \\
(\%)\end{array}$ & $\begin{array}{c}\text { EC } \\
\text { dsm }^{-1}\end{array}$ & \begin{tabular}{|c|} 
Field \\
capacity \\
$(\%)$
\end{tabular} & $\begin{array}{c}\text { Real } \\
\text { density } \\
\left(\mathrm{g} / \mathrm{cm}^{3}\right)\end{array}$ \\
\hline $2005 / 2006$ & Clay loam & 6.2 & 32. & & 24.7 & 35.5 & 2.45 & 2.2 & 34.3 & 2.66 \\
\hline \begin{tabular}{|l|}
$2006 / 2007$ \\
\end{tabular} & Clay loam & 5.8 & 33. & & \begin{tabular}{l|l}
5.3 \\
\end{tabular} & 35.7 & 2.54 & 2.4 & 35.2 & 2.65 \\
\hline \multicolumn{11}{|c|}{ Chemical characteristics } \\
\hline \multirow{2}{*}{\begin{tabular}{|l|} 
Properties \\
Seasons
\end{tabular}} & \multirow{2}{*}{$\begin{array}{l}\text { pH soil } \\
\text { paste }\end{array}$} & \multirow{2}{*}{\multicolumn{2}{|c|}{$\begin{array}{c}\text { Organic } \\
\text { matter (\%) }\end{array}$}} & \multirow{2}{*}{\multicolumn{3}{|c|}{$\begin{array}{c}\text { CEC } \\
\mathrm{meq} / 100 \mathrm{~g}\end{array}$}} & \multicolumn{4}{|c|}{ Available nutrients (ppm) } \\
\hline & & & & & & & $\mathbf{N}$ & & $\mathbf{P}$ & K \\
\hline $2005 / 2006$ & 7.6 & 1.72 & & & 53.2 & & 32.3 & & 4.4 & 315 \\
\hline $2006 / 2007$ & 7.8 & 1.83 & & & 50.7 & & 36.4 & & 5.3 & 324 \\
\hline
\end{tabular}

From Table (1), it could be seen that soil contents from available $P$ and $\mathrm{K}$ are adequate enough for wheat crop. The cultivation took place in November $23^{\text {rd }}$ and $26^{\text {th }}$ in the first and second seasons, respectively. Wheat grains cultivar Giza 168 at the rate of $60 \mathrm{~kg} / \mathrm{fed}$ were sown by using broadcasting Afir method. The common agricultural practices for growing wheat according to the recommendations of Ministry of Agriculture were followed, except the factors under study. 
Farouk, S.

At 90 days after sowing (DAS) nine plants were harvested from each replicate for determination some growth parameters (flag leaf area, number of leaves per plant, shoot dry weight) and some physiological characteristics (photosynthetic pigments, total carotenoids, total carbohydrates, and soluble protein and nitrogen contents in the flag leaf). Moreover, culm and flag leaf anatomical features of the best selected treatments and both moderate and high nitrogen rates were studied. At harvest, the grain yields per plant and grain weight per main spike were determined.

Flag leaf area $\left(\mathrm{cm}^{2}\right)$ was calculated by the following formula $a=L \times W$ $\times 0.75$ (Gardner et al., 1985). Photosynthetic pigments were extracted for 24 $\mathrm{hr}$. at room temperature in methanol after adding traces of sodium carbonate. Photosynthetic pigments concentrations were determined spectrophotometrically according to Lichtenthaler and Wellburn (1985). Soluble protein concentration was measured at $595 \mathrm{~nm}$ using bovine serum albumin as standard according to the method of Bradford (1976).

For ion content, dry flag leaf samples were digested with $\mathrm{HClO}_{3} / \mathrm{H}_{2} \mathrm{SO}_{4}$ until the solution was clear, cooled, and brought to volume at $50 \mathrm{ml}$ using deionized water. Nitrogen was determined by microkjeldahl methods (Jackson, 1973). Total carbohydrates content were estimated using the anthrone method as described by Sadasivam and Manickam (1996).

The best treatments as compared to moderate (recommended rate) rate were anatomical studied in the second season. Flag leaf segment and small blocks about $1 \mathrm{~cm}$ in thickness from the middle portions of the basal internodes of the mature wheat culms were taken. The samples were fixed immediately in formalin-acetic-alcohol for $48 \mathrm{~h}$, and then dehydrated in a series of $n$-butanole series. The completely dehydrated specimens were immersed into paraffin wax $\left(52-54^{\circ} \mathrm{C}\right.$ melting points). Cross sections of $15-17$ $\mu \mathrm{m}$ thick were prepared by a rotary microtome, stained with erythrosin/crystal violet and mounted in canada balsam for discriminating leaf or culm internal structures. The sections were examined microscopically for determining the anatomical changes.

All obtained data were statistically analyzed according to the technique of analysis of variance (ANOVA) for the split-plot design by means of "MSTAT-C" computer software package as published by Gomez and Gomez (1984).

\section{RESULTS}

\section{Plant growth and yield}

Foliar application with micronutrients treatments, in particular, combined mixture of micronutrients at the rate of $500 \mathrm{ppm}$ from each, increased significantly all studied growth and yield characters i.e., flag leaf area, number of leaves per plant, shoot dry weight, grain weight per main spike and grain yield per wheat plant in both seasons (Table, 2) as compared with water or control plants. The combined mixture of micronutrients produced the highest values of plant growth and yield characters in both seasons followed by either zinc or manganese; meanwhile both iron and 
copper gave the lowest value of studied characters followed by water spraying and control plants. The data in the same Table clearly indicate that application of nitrogen fertilizer rates from 50 to $90 \mathrm{~kg} \mathrm{~N} / \mathrm{fed}$ increased significantly and gradually all growth and yield characters of wheat plant in the two growing seasons.

Table 2: Flag leaf area $\left(\mathrm{cm}^{2}\right)$, number of leaves per plant, shoot dry weight $(g)$, grains weight/main spike $(g)$ and grain yield per plant $(\mathrm{g})$ as affected by $\mathrm{N}$-rates and foliar application with micronutrients as well as their interactions during 2005/2006 and $2006 / 2007$ seasons.

\begin{tabular}{|c|c|c|c|c|c|c|c|c|c|c|c|}
\hline \multirow[t]{2}{*}{ Treatments } & \multirow[t]{3}{*}{ Characters } & \multicolumn{2}{|c|}{$\begin{array}{c}\text { Flag leaf } \\
\text { area } \\
\left(\mathrm{cm}^{2}\right)\end{array}$} & \multicolumn{2}{|c|}{$\begin{array}{l}\text { No of leaves } \\
\text { per plant }\end{array}$} & \multicolumn{2}{|c|}{$\begin{array}{l}\text { Shoot dry } \\
\text { weight (g) }\end{array}$} & \multicolumn{2}{|c|}{$\begin{array}{c}\text { Grains } \\
\text { weight/ } \\
\text { main spike } \\
\text { (g) }\end{array}$} & \multicolumn{2}{|c|}{$\begin{array}{l}\text { Grain yield } \\
\text { per plant }(g)\end{array}$} \\
\hline & & 2006 & \begin{tabular}{|l|}
$2006 /$ \\
2007 \\
\end{tabular} & $\begin{array}{l}2005 / \\
2006\end{array}$ & \begin{tabular}{|l|}
$2006 /$ \\
2007 \\
\end{tabular} & \begin{tabular}{|l|}
$2005 /$ \\
2006 \\
\end{tabular} & \begin{tabular}{|l|}
$2006 /$ \\
2007 \\
\end{tabular} & $\begin{array}{l}2005 / \\
2006 \\
\end{array}$ & \begin{tabular}{|l|}
$2006 /$ \\
2007 \\
\end{tabular} & $\begin{array}{l}2005 / \\
2006\end{array}$ & $\begin{array}{l}2006 / \\
2007 \\
\end{array}$ \\
\hline \multicolumn{11}{|c|}{ A-Foliar application with micronutrients: } & \\
\hline \multicolumn{2}{|l|}{ Untreated } & 33.65 & 30.42 & 16.88 & 33 & 12.24 & 12.09 & .30 & 2.20 & 514 & 8.587 \\
\hline \multicolumn{2}{|l|}{ Water } & 35 & 33.05 & 17.00 & 3.66 & 12.45 & 12.19 & 2.46 & 2.36 & 713 & 557 \\
\hline \multicolumn{2}{|l|}{ Cu 500 ppm } & 37.84 & 35.68 & 16.77 & 3.66 & 12.50 & 12.17 & 2.65 & 2.58 & .711 & 599 \\
\hline \multicolumn{2}{|l|}{ Mn 500 ppm } & 38.79 & 36.56 & 17.77 & 17.33 & 12.97 & 12.57 & 2.73 & 2.63 & 9.089 & 930 \\
\hline \multicolumn{2}{|l|}{ Fe 500 ppm } & 38.05 & 34.98 & 17.55 & 17.33 & 12.82 & 12.51 & 2.67 & 2.61 & 8.997 & 8.866 \\
\hline \multicolumn{2}{|l|}{ Zn 500 ppm } & 39.90 & 37.43 & 17.66 & 17.11 & 12.81 & 12.50 & 2.80 & 2.67 & 9.033 & 8.828 \\
\hline \multicolumn{2}{|c|}{ Combined mixture } & 42.46 & 40.24 & 18.55 & 17.55 & 13.23 & 12.79 & 2.96 & 2.86 & 9.248 & 9.047 \\
\hline \multicolumn{2}{|c|}{ LSD $5 \%$} & 0.57 & 0.70 & 0.339 & 0.240 & 0.130 & 0.078 & 0.05 & 0.05 & 0.114 & 0.070 \\
\hline \multicolumn{2}{|l|}{$50 \mathrm{~kg} \mathrm{~N} / \mathrm{fed}$} & 33.18 & 0 & 5.52 & .33 & 6 & 57 & 2.45 & 2.36 & 77 & \\
\hline \multicolumn{2}{|l|}{$70 \mathrm{~kg} \mathrm{~N} / \mathrm{fed}$} & 39.24 & 37.42 & 17.52 & \begin{tabular}{|l|l|}
17.14 \\
\end{tabular} & 12.67 & 12.43 & 2.70 & 2.60 & 8.915 & 8.799 \\
\hline \multicolumn{2}{|l|}{$90 \mathrm{~kg} \mathrm{~N} / \mathrm{fed}$} & 41.63 & 39.33 & 19.33 & 18.52 & 13.62 & 13.21 & 2.80 & 2.71 & 9.610 & 9.399 \\
\hline \multicolumn{2}{|l|}{ LSD $5 \%$} & 1.33 & 2.21 & 0.222 & 0.157 & 0.085 & 0.051 & 0.15 & 0.10 & 0.075 & 0.046 \\
\hline \multirow{3}{*}{ Untreated } & & 20 & & & & 63 & & 2.05 & 1.98 & 20 & 7.423 \\
\hline & $70 \mathrm{~kg} \mathrm{~N} / \mathrm{fed}$ & 35.90 & 32.52 & 00 & 00 & 12.76 & 12.59 & 2.41 & 2.25 & 8.920 & 8.843 \\
\hline & $90 \mathrm{~kg} \mathrm{l}$ & 38.46 & 35.72 & 0 & 3.66 & 13.33 & 13.17 & 2.45 & 2.38 & .603 & 9.493 \\
\hline \multirow{3}{*}{ Water } & $50 \mathrm{~kg} \mathrm{~N} / \mathrm{fed}$ & 28.28 & 25.86 & 16.00 & 16.00 & 12.19 & 11.84 & 2.25 & 2.10 & 8.433 & 8.327 \\
\hline & $70 \mathrm{~kg} \mathrm{~N} / \mathrm{fed}$ & 37.83 & 35.81 & 19.00 & 18.00 & 13.20 & 13.03 & 2.59 & 2.45 & 9.430 & 9.230 \\
\hline & $90 \mathrm{~kg} \mathrm{~N} / \mathrm{fed}$ & 40.13 & 37.49 & 16.00 & 16.00 & 11.97 & 11.72 & 2.56 & 2.53 & 8.277 & 8.113 \\
\hline \multirow{3}{*}{$\mathrm{Cu}$} & $50 \mathrm{k}$ & 33.30 & & & 17.00 & 12.60 & 12.29 & 2.46 & 2.39 & 8.787 & 8,697 \\
\hline & $70 \mathrm{~kg} \mathrm{I}$ & 39.34 & 38.00 & 15.00 & 15.00 & 11.80 & 11.43 & 2.69 & 2.63 & 8.123 & 8.033 \\
\hline & $90 \mathrm{~kg}$ & 40.89 & 38.91 & 3 & 00 & 13.10 & 79 & 2.78 & 2.72 & 9.223 & 9.067 \\
\hline \multirow{3}{*}{ Mn } & $50 \mathrm{~kg} \mathrm{~N} / \mathrm{fed}$ & 35.30 & 31.43 & 14.00 & 14.00 & 11.26 & 10.75 & 2.54 & 2.44 & 7.707 & 7.560 \\
\hline & $70 \mathrm{~kg} \mathrm{~N} / \mathrm{fed}$ & 39.50 & 38.30 & 18.00 & 18.00 & 12.91 & 12.75 & 2.76 & 2.67 & 9.067 & 9.027 \\
\hline & $90 \mathrm{~kg} \mathrm{~N} / \mathrm{fed}$ & 41.57 & 39.95 & 21.33 & 20.00 & 14.75 & 14.22 & 2.89 & 2.77 & 10.49 & 10.20 \\
\hline \multirow{3}{*}{$\mathrm{Fe}$} & $50 \mathrm{~kg} \mathrm{~N} / \mathrm{fed}$ & 33.83 & 28.52 & 16.00 & 16.00 & 12.30 & 12.05 & 2.48 & 2.41 & 8.550 & 8.427 \\
\hline & $70 \mathrm{~kg} \mathrm{~N} / \mathrm{fed}$ & 39.22 & 38.03 & 19.66 & 19.00 & 13.65 & 13.31 & 2.71 & 2.65 & 9.803 & 9.647 \\
\hline & $90 \mathrm{~kg}$ & 41.10 & 38.40 & 17.00 & 17.00 & 12.50 & 12 & 2.82 & 2.77 & 8.637 & 8.557 \\
\hline & $50 \mathrm{~kg} \mathrm{l}$ & 36.45 & 32.60 & 17.66 & 17.00 & 12.63 & 12.52 & 2.60 & 2.49 & 8.850 & 8.740 \\
\hline $\mathrm{Zn}$ & $70 \mathrm{~kg} \mathrm{~N} / \mathrm{fed}$ & 40.48 & 38.94 & 15.00 & 15.00 & 11.64 & 11.25 & 2.82 & 2.71 & 8.047 & 7.893 \\
\hline & $90 \mathrm{~kg} \mathrm{~N} / \mathrm{fed}$ & 42.78 & 40.75 & 20.33 & 19.33 & 14.16 & 13.72 & 2.98 & 2.83 & 10.20 & 9.850 \\
\hline & $50 \mathrm{~kg} \mathrm{~N} / \mathrm{fed}$ & 38.51 & 36.33 & 14.33 & 14.00 & 11.42 & 11.04 & 2.78 & 2.71 & 7.893 & 7.713 \\
\hline & $70 \mathrm{~kg} \mathrm{~N} / \mathrm{fed}$ & 42.41 & 40.33 & 18.00 & 18.00 & 12.77 & 12.69 & 2.95 & 2.87 & 9.017 & 8.920 \\
\hline & $90 \mathrm{~kg} \mathrm{f}$ & 46.48 & 44.07 & 23.33 & 20.66 & 15.50 & 14.63 & 3.16 & 3.00 & 10.83 & 10.50 \\
\hline \begin{tabular}{|l} 
LSD \\
$5 \%$
\end{tabular} & & \begin{tabular}{|l|}
0.98 \\
\end{tabular} & 1.22 & 0.587 & 0.415 & 0.225 & 0.135 & 0.08 & NS & 0.198 & 0.122 \\
\hline
\end{tabular}


Farouk, S.

Regarding to the interaction effects, the data in Table (2) reveal that application of micronutrient, in particular, combined mixture of micronutrients under all nitrogen rates increased significantly all studied characters as compared with nitrogen levels alone or application of water as foliar application in the two growing seasons. The highest values of all studied growth and yield characters were obtained due to application of combined mixture of micronutrients followed by zinc under high rate of nitrogen fertilizer (90 kg N/Fed).

\section{Physiological characters:}

Application of micronutrients, in particular, the combined mixture of micronutrients at the rate of $500 \mathrm{mg} / \mathrm{l}$ from each, increased significantly all physiological parameter i.e. total chlorophyll, total carotenoids, total carbohydrates, total soluble protein and total nitrogen content in flag leaf in both growing seasons, followed by iron or manganese, zinc and finally copper (Table 3). The data presented in the same Table reveal that raising nitrogen fertilizers rates significantly increased all studies physiological characters. The highest content of all physiological components were obtained with high nitrogen level.

As regard to the interactions between micronutrients and nitrogen rates the data presented in the same Table indicate that application of any micronutrients alone or the combined mixture of micronutrients improved significantly all physiological characters in both seasons. The best interaction treatment which produced the highest values of these characters was foliar application with the combined mixture of each micronutrients at the rate of $500 \mathrm{ppm}$ under high rate of nitrogen fertilizer $(90 \mathrm{~kg} \mathrm{~N} / \mathrm{fed})$.

\section{Anatomical studies Leaf anatomy:}

There is the tremendous variety shown in leaf blade structure from species to species, yet the basic organization of internal tissues and the developmental pathways are similar. The epidermis, mesophyll, and veins are three basic tissues of a leaf blade of most vascular plants including wheat (Figure 1). Leaf anatomical characters, such as thickness of upper epidermis (UE), thickness of lower epidermis (LE), thickness of leaf through midrib (TL), tangential dimension of midrib vascular bundle (TDMVB), tangential dimension of big xylem vessel (TDBXV), and thickness of mesophyll tissue (M) of flag leaf were studied in the best selected treatments as compared with moderate and high nitrogen rates.

Cross section of wheat flag leaves (Figure 1) showed that there were significant changes in leaf anatomical characteristics induced by application of micronutrients combined mixture or both zinc and manganese under both moderate and high nitrogen rates as compared with moderate and high nitrogen rates (Table, 4; Figure, 1). Application of combined mixture of micronutrient or Zinc and Mn under high rate of nitrogen increased the thickness of wheat flag leaf blade, due to the increase in the thickness of mesophyll tissue as well as thickness of both lower and upper epidermis cells as compared with moderate or high nitrogen rates alone. In addition, the thickness of flag leaf blade through midrib region was also increased 
respectively, due to the increase in the midrib vascular bundle, as well as tangential and radial dimensions of big metaxylem vessel as compared with moderate nitrogen rate (Table 4 and figure 1). Moreover the same table and figure indicate that application of combined mixture of micronutrient under moderate nitrogen rate increased all anatomical characteristics as compared with moderate nitrogen rate.

Table 3: Total chlorophyll (mg/g FW), Total carotenoids (mg/g FW), Total carbohydrates (mg/g DW), Soluble proteins ( $\mathrm{mg} / \mathrm{g} \mathrm{FW}$ ) and Nitrogen content $(\mathrm{mg} / \mathrm{g} \mathrm{DW})$ in flag leaf as affected by foliar application with micronutrients and nitrogen rates as well as their interactions during $2005 / 2006$ and $2006 / 2007$ seasons.

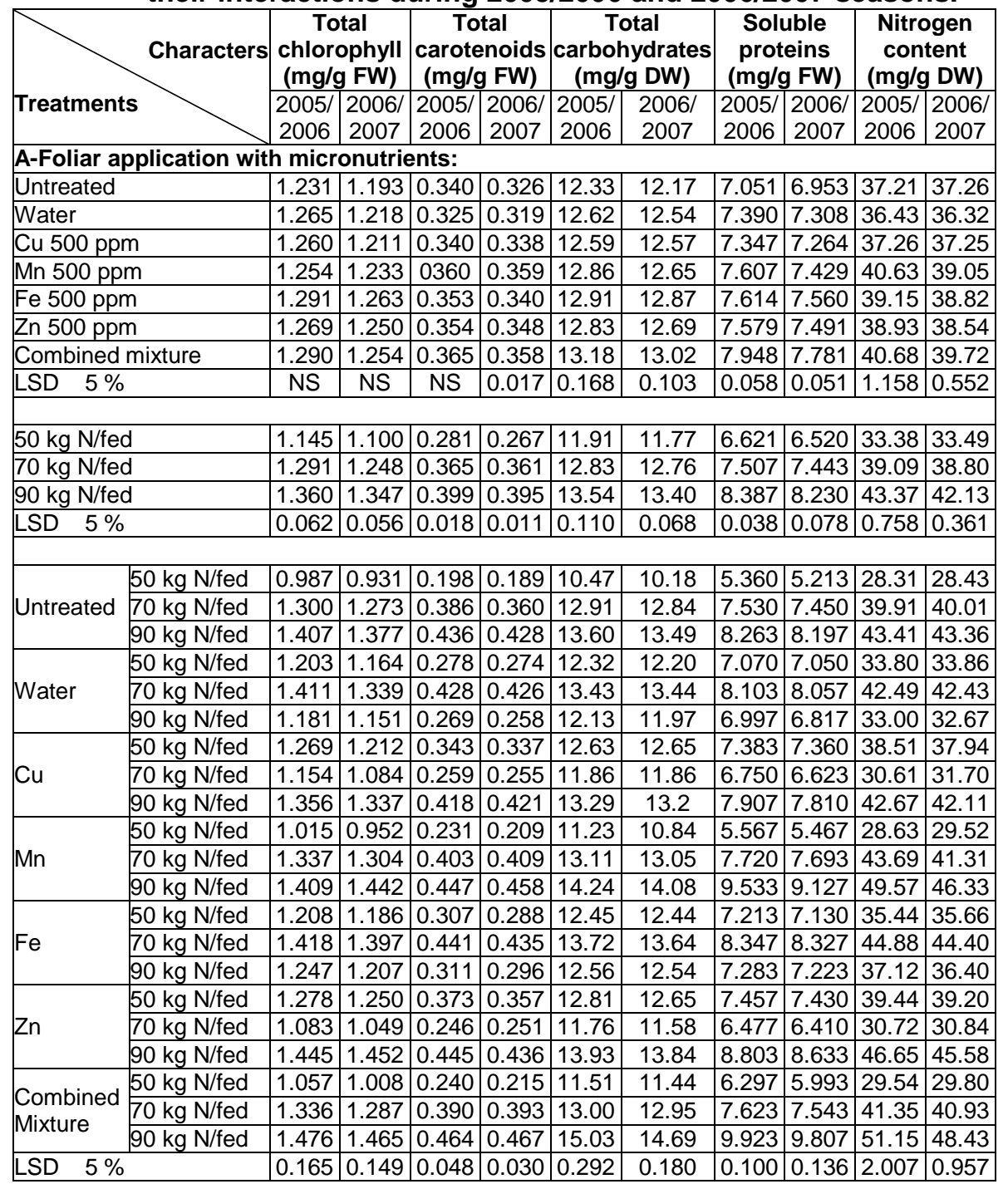


Farouk, S.

Table (4): Leaf anatomical characteristics $(\mu)$ of flag leaf of wheat plants at 90 days after sowing as affected by the best treatments as compared with moderate and high nitrogen rates in the second season.

\begin{tabular}{|c|c|c|c|c|c|c|c|c|c|c|c|c|}
\hline \multirow[t]{2}{*}{ Treatment } & \multicolumn{2}{|c|}{$\begin{array}{c}\text { Thickness } \\
\text { of upper } \\
\text { epidermis } \\
\text { (UE) }\end{array}$} & \multicolumn{2}{|c|}{$\begin{array}{l}\text { Thickness } \\
\text { of lower } \\
\text { epidermis } \\
\text { (LE) }\end{array}$} & \multicolumn{2}{|c|}{$\begin{array}{l}\text { Thickness } \\
\text { of leaf } \\
\text { through } \\
\text { midrib } \\
\text { (TL) }\end{array}$} & \multicolumn{2}{|c|}{$\begin{array}{c}\text { Tangential } \\
\text { dimension } \\
\text { of midrib } \\
\text { vascular } \\
\text { bundle } \\
\text { (TDMVB) }\end{array}$} & \multicolumn{2}{|c|}{$\begin{array}{c}\text { Tangential } \\
\text { dimension } \\
\text { of big } \\
\text { xylem } \\
\text { vessel } \\
\text { (TDBXV) }\end{array}$} & \multicolumn{2}{|c|}{\begin{tabular}{|} 
Thickness \\
of \\
mesophyll \\
tissue \\
(M)
\end{tabular}} \\
\hline & $\mu$ & $\%$ & 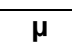 & $\%$ & $\mu$ & $\%$ & $\mu$ & $\%$ & $\mu$ & $\%$ & $\mu$ & $\%$ \\
\hline $\begin{array}{l}70 \mathrm{Kg} N \mathrm{~N} / \mathrm{Fad} \\
(\text { recommended) }\end{array}$ & 3.96 & 100 & 3.42 & 100 & 113.30 & 100 & 63.98 & 100 & 6.41 & 100 & 78.42 & 100 \\
\hline $90 \mathrm{Kg} \mathrm{N} / \mathrm{Fad}$ & 4.10 & 103 & 3.84 & 112 & 128.35 & 113 & 69.11 & 107 & 7.48 & 116 & 86.75 & 110 \\
\hline $\mathrm{Mn}+90 \mathrm{Kg} \mathrm{N} / \mathrm{Fad}$ & 4.22 & 106 & 3.93 & 114 & 153.82 & 135 & 69.83 & 109 & 8.03 & 125 & 91.15 & 116 \\
\hline $\begin{array}{l}\text { Combined mixture } \\
+70 \mathrm{Kg} \mathrm{N} / \text { Fad }\end{array}$ & 4.61 & 116 & 4.07 & 119 & 193.32 & 170 & 72.01 & 112 & 9.90 & 154 & 96.15 & 122 \\
\hline $\mathrm{Zn}+90 \mathrm{Kg} \mathrm{N} / \mathrm{Fad}$ & 4.92 & 124 & 4.13 & 120 & 223.22 & 197 & 74.71 & 116 & 9.45 & 147 & 102.95 & \begin{tabular}{|l|l|}
5131 \\
\end{tabular} \\
\hline $\begin{array}{l}\text { Combined mixture } \\
+90 \mathrm{Kg} \mathrm{N} / \text { Fad }\end{array}$ & 5.20 & 131 & 4.42 & 129 & 233.04 & 205 & 75.44 & 117 & 9.01 & 140 & 109.21 & $\begin{array}{l}139 \\
\end{array}$ \\
\hline
\end{tabular}
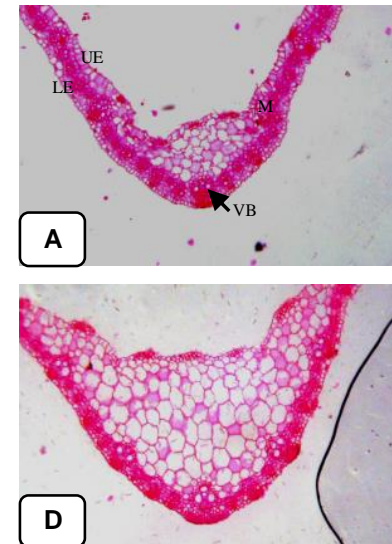
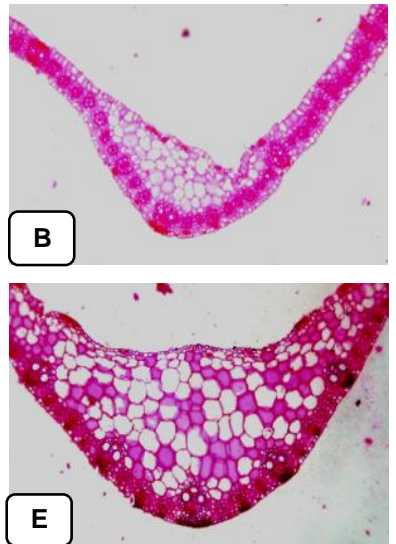
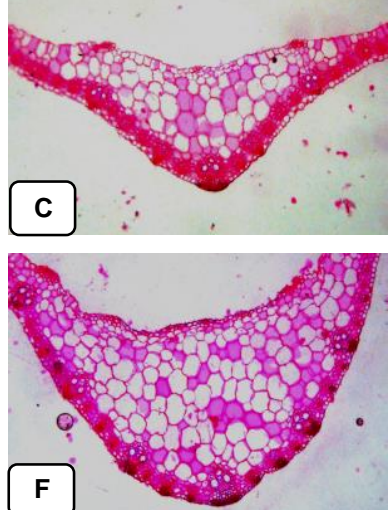

Figure 1: Leaf anatomical characteristics $(\mu)$ of flag leaf of wheat plants at 90 days after sowing as affected by the best treatments as compared with moderate nitrogen rate in the second season. (A: $70 \mathrm{Kg} \mathrm{N} /$ Fad, B: $90 \mathrm{Kg} \mathrm{N}$ / Fad; C: $\mathrm{Mn}+90 \mathrm{Kg} \mathrm{N} /$ Fad; D: Combined mixture + $70 \mathrm{Kg} \mathrm{N} /$ Fad; E: $\mathrm{Zn}+90 \mathrm{Kg} \mathrm{N} /$ Fad; F: Combined mixture + $90 \mathrm{Kg} \mathrm{N} /$ Fad; UE: upper epidermis; LE: lower epidermis, VB: vascular bundles), 40x

Culm structure:

The anatomical characteristics among the best selected treatments as compared to moderate nitrogen fertilizer rate are summarized in Table (5) and figure (2). It is evident that there was an increase in the diameter of culm 
associated with increasing the thickness of culm wall, mechanical tissue thickness and the thickness of big metaxylem vessel as well as number of vascular bundles due to application of micronutrients, in particular, combined mixture of micronutrient as compared with moderate nitrogen rate. Meanwhile, application of nitrogen rate up to $90 \mathrm{~kg} \mathrm{~N} / \mathrm{fed}$ increased the thickness of vascular bundles as compared with all selected treatments.

Table (5): Culm anatomical characteristics $(\mu)$ of wheat plants at 90 days after sowing as affected by the best treatment as compared with moderate nitrogen rate in the second season.

\begin{tabular}{|c|c|c|c|c|c|c|c|c|c|c|c|c|}
\hline \multirow[t]{2}{*}{ Treatment } & \multicolumn{2}{|c|}{$\begin{array}{c}\text { Diameter } \\
\text { of Culm } \\
(\mathrm{mm})\end{array}$} & \multicolumn{2}{|c|}{$\begin{array}{c}\text { Thickness } \\
\text { of culm } \\
\text { wall }(\mu)\end{array}$} & \multicolumn{2}{|c|}{$\begin{array}{c}\text { Mechanical } \\
\text { tissue } \\
\text { thickness } \\
(\mu)\end{array}$} & \multicolumn{2}{|c|}{$\begin{array}{c}\text { Number } \\
\text { of } \\
\text { vascular } \\
\text { bundles }\end{array}$} & \multicolumn{2}{|c|}{$\begin{array}{c}\text { Thickness } \\
\text { of big } \\
\text { vascular } \\
\text { bundles } \\
(\mu)\end{array}$} & \multicolumn{2}{|c|}{$\begin{array}{l}\text { Thickness } \\
\text { of big } \\
\text { metaxylem } \\
\text { vessel } \\
(\mu)\end{array}$} \\
\hline & $\mu$ & $\%$ & $\mu$ & $\%$ & $\mu$ & $\%$ & $\mu$ & $\%$ & $\mu$ & $\%$ & $\mu$ & $\%$ \\
\hline $70 \mathrm{Kg} \mathrm{N} / \mathrm{Fad}$ & 3.73 & 100 & 553.38 & 100 & 79.24 & 100 & 22.66 & 100 & 55.61 & 100 & 7.64 & 100 \\
\hline $90 \mathrm{Kg} \mathrm{N} / \mathrm{Fad}$ & 0 & 107 & 594.43 & 107 & 84.68 & 106 & 27.33 & 120 & 78.89 & 141 & 8.32 & 108 \\
\hline $\mathrm{Mn}+90 \mathrm{Kg} \mathrm{N} / \mathrm{Fad}$ & 78 & 128 & 734.61 & 132 & 80 & 115 & 34.33 & 151 & 73.70 & 132 & 8.73 & 114 \\
\hline $\begin{array}{l}\text { Combined mixture }+70 \mathrm{Kg} \mathrm{N} \\
\text { Fad }\end{array}$ & .28 & 141 & 768.98 & 138 & 69.07 & 87 & 38.33 & 169 & 61.82 & 111 & 9.04 & 118 \\
\hline $\mathrm{Zn}+90 \mathrm{Kg} \mathrm{N} / \mathrm{Fad}$ & 82 & 156 & 915.24 & 165 & 54.39 & 68 & 40.66 & 178 & 67.87 & 122 & 9.65 & 126 \\
\hline $\begin{array}{l}\text { Combined mixture + } 90 \mathrm{Kg} \mathrm{N} \\
\text { Fad }\end{array}$ & .40 & 171 & 937.47 & 169 & 98.31 & 124 & 4 & 204 & 65.22 & 117 & 10.1 & 132 \\
\hline
\end{tabular}

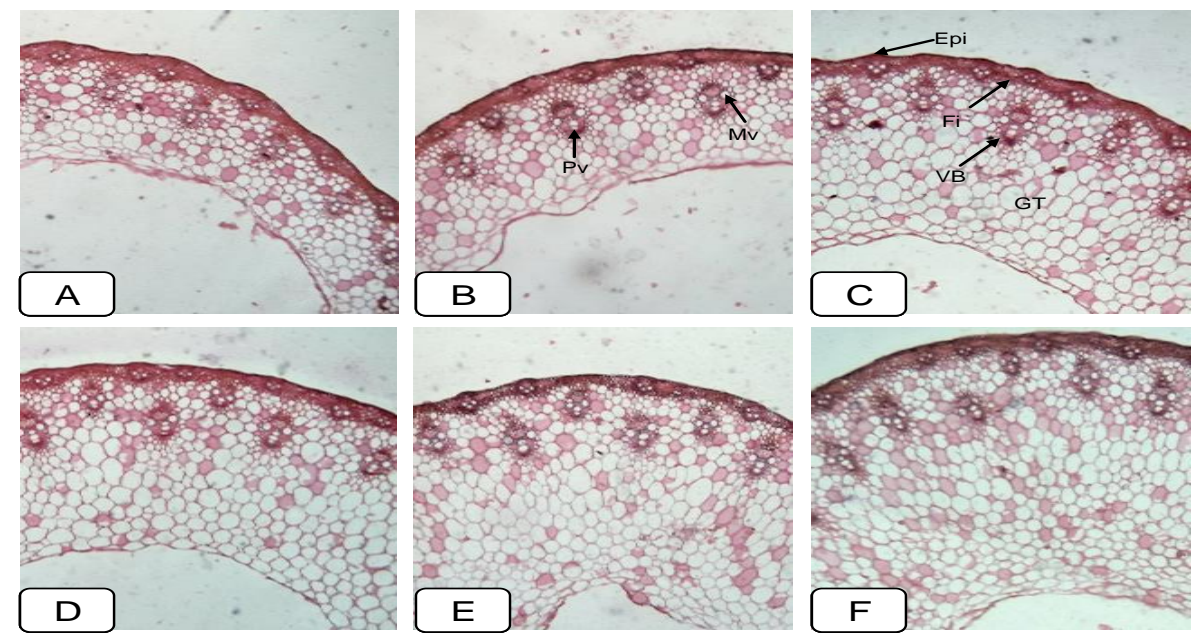

Figure 2: Culm anatomical characteristics $(\mu)$ of wheat plants at 90 days after sowing as affected by the best treatment as compared with moderate nitrogen rate in the second season. (A: $70 \mathrm{Kg}$ N / Fed, B: $90 \mathrm{Kg} \mathrm{N}$ / Fed; C: $\mathrm{Mn}+90 \mathrm{Kg} \mathrm{N} /$ Fed; D: Combined mixture + 70 Kg N / Fed; E: Zn + 90 Kg N / Fed; F: Combined mixture + $90 \mathrm{Kg} \mathrm{N}$ / Fed; PV: protoxylem vessel; MV: metaxylem vessel; Epi: epidermis; Fi: fiber; VB: vascular bundle; GT: ground tissue), 40x. 
Farouk, S.

\section{DISCUSSION}

The roles of micronutrients, in particular, combined mixture of micronutrients on stimulating plant growth and increasing grain yield in our investigation, may be due to increasing nitrogen content in flag leaf, which playing an important role in increasing photosynthetic rate due to its role in increasing the activity of key enzyme of $\mathrm{CO}_{2}$ fixation; ribulose-1,5bisphoosphate carboxylase/oxygenase (RuBisco, EC 4.1.1.39) (Sage and Monson, 1999), in addition to the role of nitrogen in increasing photosynthetic pigments as well as total carbohydrates content in flag leaf. Also, from this study it could be concluded that application of micronutrient under moderate and high nitrogen rates increased significantly all anatomical characteristics specially the number of vascular bundles in culm, thickness of vascular bundles, and big metaxylem vessel in both leaf and culm as well as thickness of mesophyll tissue in flag leaf. Leaf thickness and mean mesophyll cell size were found directly related to light-saturated photosynthesis per unit leaf area in $\mathrm{C}_{3}$ grasses (Nobel et al., 1975). A better photosynthetic rate was also demonstrated in $\mathrm{C}_{3}$ plants of thicker leaves and higher ratio of total surface area of the mesophyll cells to leaf area (Araus et al., 1986). These results provide a clear picture that $\mathrm{CO}_{2}$ movement through stomata to the carboxylation sites (mesophyll cells) is facilitated in conditions of large area ratios of mesophyll cells to leaf and thicker leaves, and thus enhance photosynthetic rate and increasing the content of photoassimilate which translocate from leaves to growing grain through vascular bundles resulted in increasing grain yield.

The most promising results from this study indicate that application of combined mixture of micronutrients increased significantly the culm diameter as well as the thickness of culm wall and mechanical tissue and the number of vascular bundles leading to increasing grain yield per plant and grain weight per spike. Literatures are numerous focused on the culm anatomical features in relation to grain yield of wheat (Wang et al., 1995). Wang et al (2000) concluded that culm diameter, thickness of mechanical tissue and the number of vascular bundles are important features of high yield of wheat cultivar. In addition, vascular bundles, the essential conducting tissue, form the most complicated network in the plant body. They transmit signals and transport materials from roots to stems and leaves, and also from storagetissues to other tissues. The extent of vascular bundle development affects the transportation of assimilates and inorganic nourishment, and sometimes it is a vital factor for improving wheat yield. The conducting systems of various yield-potential cultivars were analyzed and the results showed that their degree of complexity is in agreement with the yield potential of the cultivar. So, to some extent, different sizes and distribution of vascular bundles are the positive factors for spike weight. In this investigation, the number and thickness of vascular bundle and thickness of big metaxylem vessel in best treatment confirmed this conclusion.

The specific effect of each micronutrient may be summarized as fellow. Foliar spraying with zinc encouraged the vegetative growth and 
increased the plant capacity for building metabolites. Such response may be due to that zinc is known to play an activator of over 300 enzymes in plants (Fox and Guerimot, 1998) and is directly involved in the biosynthesis of growth substances such as auxin, Indole acetic acid in particular (Maischner, 2002) which produces more plant cells and more dry matter. These stimulating effects of zinc might be due to better utilization of available zinc by the plants because of exogenous supplementation. Zinc application have favorable effect in pollen germination, tube elongation and in decreasing the number of ruptured pollen which results in better fertilization, higher seed set and increased seed yield. Zinc plays a vital role as activation of carbohydrate and protein synthesis as well as their transport to the site of seed formation. The present results were in conformity with Manoharan et al .(2001) in rice and Seadh et al. (2009) in wheat. Moreover, Abd El-Monem et al. (2009) found that treated broad bean and lupin plants with zinc significantly stimulated the most of the growth and yield characteristics, increases in the contents of photosynthetic pigments, soluble carbohydrates and soluble proteins as well as gibberellic acid $\left(\mathrm{GA}_{3}\right)$ and indole acetic acid (IAA). Moreover, application of $\mathrm{Zn}$ increased significantly photosynthetic pigments contents as well as total carbohydrate contents. This increase could be ascribed to the effect of this element on increasing the biosynthesis of photosynthetic pigments and/or retarding their degradation. The results of (Tobbal, 2006) proved these observations. Concerning soluble protein the present investigation indicate that application of $\mathrm{Zn}$ increased significantly soluble protein. These results were confirmed with Gamal El-Din (2005).

Very extensive studies have been made on the forms and behavior of $\mathrm{Cu}$ in plants. All findings described in a number of outstanding textbooks can be summarized as follows: 1) $\mathrm{Cu}$ is mainly complexes with organic compounds of low molecular weight and with proteins; 2) $\mathrm{Cu}$ occurs in the compounds with no known functions as well as in enzymes having vital functions in plant metabolism; 3) Cu plays a significant role in several physiological processes-photosynthesis, respiration, carbohydrate distribution, $\mathrm{N}$ reduction and fixation, protein metabolism, and cell wall metabolism; 4) Cu influences water permeability of xylem vessels and thus controls water relationships, and finally 5 ) $\mathrm{Cu}$ controls the production of DNA and RNA, and its deficiency greatly inhibits the reproduction of plants (reduced seed production, pollen sterility). In cereal crops, copper is required for anther and pollen development, and deficiencies can lead to pollen abortion and male sterility (Wojnarowiez et al., 2002). In addition, copper deficiency limits the activity of many plant enzymes, including ascorbate oxidase, phenolase, cytochrome oxidase, diamine oxidase, plastocyanin, and superoxide dismutase (Walker and Webb, 1981), also depresses carbon dioxide fixation, electron transport, and thylakoid prenyl lipid synthesis relative to plants receiving full nutrition (Bussler, 1981). The most important practical implications are related to deficiency and toxicity of $\mathrm{Cu}$.

Manganese is involved in many biochemical functions, primarily acting as an activator of enzymes such as dehydrogenases, transferases, hydroxylases, and decarboxylases involved in respiration, amino acid and 


\section{Farouk, S.}

lignin synthesis, and hormone concentrations (Burnell, 1988). Manganese is involved in oxidation-reduction (redox) reactions within the photosynthetic electron transport system in plants (Amesz, 1993). Manganese is also involved in the photosynthetic evolution of $\mathrm{O}_{2}$ in chloroplasts (Hill reaction). Owing to the key role in this essential process, inhibition of photosynthesis occurs even at moderate manganese deficiency. The increase in soluble proteins due to manganese application is thought to be due to the role of this element in activating RNA polymeraze enzyme (Ness and Woolhouse, 1980). Lerer and Bar-Akiva (1976) likewise reported that increasing manganese application would mobilize nitrate formation processes, which causes more carbohydrate to be converted to proteins.

Concerning the effect of iron, there are an increase in the plant growth, yield and some physiological parameters. The increase in this parameter can be attributed to the favorable effects of active $\mathrm{Fe}$ on the synthesis of chlorophyll, and on the photosynthesis (Rao et al., 2001). As well as being a constituent of the heme group, iron is required at two other stages in its manufacture. It activates the enzymes aminolevulinic acid synthetase and coproporphorinogen oxidase. The protoporphyrin synthesized as a precursor of heme is also a precursor of chlorophyll, and although iron is not a constituent of chlorophyll this requirement, and the fact that it is also required for the conversion of $\mathrm{Mg}$ protoporphyrin to protochlorophyllide, means that it is essential for chlorophyll biosynthesis (Marschner, 1995). However, the decreased chloroplast volume and protein content per chloroplast (Terry and Abadia, 1986) indicate that chlorophyll might not be adequately stabilized as chromoprotein in chloroplasts under iron deficiency conditions, thus resulting in chlorosis. Along with the iron requirement in some heme enzymes and its involvement in the manufacture of heme groups in general, iron has a function in Fe-S proteins, which have a strong involvement with the light-dependent reactions of photosynthesis. Ferredoxin, the end product of photosystem I, has a high negative redox potential that enables it to transfer electrons to a number of acceptors. As well as being the electron donor for the synthesis of NADPH in photosystem I, it can reduce nitrite in the reaction catalyzed by nitrite reductase and it is an electron donor for sulfite reductase. All these parameters might have contributed for optimum growth and finally for yield attributes. Apart form this increased concentration of active $\mathrm{Fe}$ in the plants with these treatments enhanced the concentration of nitrogen in the plants. As physiologically active Fe play many roles in the metabolism of nitrogen within the plants by affecting the activities of nitrate reductase which are directly involved in the assimilation of $\mathrm{N}$ (Hewitt and Notton, 1980). The increased availability and assimilation of nutrients at cellular level together with higher biomass of the plants enhanced the concentration of nutrients in the plants.

Nitrogen is one of the most important nutrients for plant growth regulation and biomass production. The present investigation indicate that increasing nitrogen rate significantly increased nitrogen content in flag leaf accompanied with increasing all physiological characters as total chlorophyll, soluble proteins and total carbohydrates. These increases resulted in 
increasing plant growth and yield. Nevertheless, four major roles for $\mathrm{N}$ have been proposed for attaining high yields of cereal plants like maize (Hageman et al., 1990), and these roles appear to be valid for many crops: 1) Establishment of photosynthetic capacity; 2) Maintenance of photosynthetic capacity; 3) Establishment of sink capacity (the number and potential size of seeds) and 4) Maintenance of functional sinks throughout seed development. Within limits, and if no other restrictive factors are present, an increase in $\mathrm{N}$ supply increases the growth, the composition of $\mathrm{N}$ and chlorophyll, and the photosynthetic capacity of leaves (Huber et al., 1989). Nitrogen supply has also been shown to regulate the synthesis of photosynthetic carboxylating enzymes, in particular, a key enzyme of $\mathrm{CO}_{2}$ fixation in photosynthesis, ribulose-1,5- bisphoosphate carboxylase/oxygenase (RuBisco, EC 4.1.1.39) in leaves (Sage and Monson, 1999), by affecting transcription and/or the stability of messenger RNA (Sugiharto and Sugiyama, 1992). Collectively, these effects result in greater light interception, higher canopy photosynthesis, and higher yield. To achieve high yields, plants must not only establish photosynthetic capacity but also continue photosynthesis throughout the grain-filling period. Thus, once established, sufficient $\mathrm{N}$ must be available to maintain the photosynthetic apparatus. This role is particularly important because dry matter accumulation in cereal grains is dependent on current photosynthesis (Swank et al., 1982). Most of the $\mathrm{N}$ in the leaf is associated with proteins in the chloroplast $-60 \%$ in $\mathrm{C}_{4}$ plants and up to $75 \%$ in $\mathrm{C}_{3}$ plants (Hageman et al., 1990) and these proteins are subject to breakdown and remobilization of the resultant amino acids.

Another important role for $\mathrm{N}$ in assuring high productivity of crop plants is establishment of reproductive sink capacity. Sink capacity of a cereal plant is a function of the number and the potential size of grains. Grain number is dependent on the number of ears per unit area, the number of florets per ear, and the proportion of florets that develop into grain and the potential size of individual grains depends on the number of endosperm cells and starch granules (Singh and Jenner, 1984). In either case, reproductive initials, like all growing tissues, are characterized by high concentrations of $\mathrm{N}$ and high metabolic activities. This need could indicate that sufficient amounts of both $\mathrm{C}$ and $\mathrm{N}$ assimilates are required for full expression of the genetic potential for initiation and early development of grains. For cereal crops, grain number is usually more closely related to yield than other yield components. Consequently, many studies have shown that $\mathrm{N}$-induced yield increases are the result of more grains per plant (Jacobs and Pearson, 1992). For wheat, this enhancement is related to an increase in tiller production and survival and to a lesser extent to a decrease in floret abortion (Thomaset al., 1978). Because vegetative development in cereal crops is negligible after flowering, the $\mathrm{N}$ subsequently acquired, or remobilized from the vegetation, is used exclusively for grain development. This need for $\mathrm{N}$ is demonstrated by the fact that adequately fertilized cereal crops typically contain from 9 to $13 \%$ protein in the grain. Indeed, some workers have suggested that the deposition and/or accumulation of storage protein by the kernel are a factor regulating grain development (Tsai et al., 1978, Tsai et al., 1980). This 
suggestion is based on the positive correlation between storage protein, kernel weight, and grain yield (Tsai et al., 1978). Other needs for $\mathrm{N}$ by developing kernels could include embryo growth and the initial and continued synthesis of enzymes needed for energy generation and the deposition of storage products in the kernel. Embryo development could affect the kernel's hormonal balance because a large portion of kernel phytohormones are produced by the embryo (Michael and Beringer, 1980). Because several of the key classes of phytohormones either contain N (auxins, cytokinins, polyamines) or are synthesized from amino acids (auxins, ethylene, polyamines), an adequate supply of $\mathrm{N}$ may be needed for their production.

It is well noted that, soluble proteins represents the first nitrogenous compounds lost during grain filling (Martignone et al., 1987) leading to a higher decrease in the yield of cereal plants, on the other hand as indicated from the present study, application of nitrogen fertilizers increased the soluble proteins in flag leaf resulted in increasing grain yield per plant. This is in conformation with the finding of Manian et al. (1987).

In conclusion, the obtained results show that foliar application with combined mixture of studied micronutrients $(\mathrm{Cu}, \mathrm{Mn}, \mathrm{Fe}$ and $\mathrm{Zn})$ at the rate of $500 \mathrm{ppm}$ from each under moderate or high rate of nitrogen fertilizer (70 or 90 $\mathrm{kg} \mathrm{N} / \mathrm{fed}$ ) can be recommended to maximize wheat grain per main spike and per plant.

\section{Acknowledgement}

We would like to thanks Prof. Dr. A. A. Arafa (Faculty of Agriculture, Mansoura University) for helpful insights and critical reviews of the manuscript.

\section{REFERENCES}

Abd El-Monem M.S., I.I. Farghal and M. R. Sofy (2009). Response of Broad Bean and Lupin Plants to Foliar Treatment with Boron and Zinc. Australian Journal of Basic and Applied Sciences, 3(3): 2226-2231.

Amesz J. (1993). The role of manganese in photosynthetic oxygen evolution. Biochim. Biophys. Acta, 726:1-12.

Araus J.L., L. Alegre, L. Tapia and R. Calafell (1986). Relationship between leaf structure and gas exchange in winter wheat leaves at different insertion levels. J. Exp. Bot., 37:1323-1333.

Bradford M.M. (1976). A rapid and sensitive method for the quantization of microgram quantities of protein utilizing the principle of protein-dye binding. Anal. Biochem., 72: 248-254.

Burnell J.N. (1988). The biochemistry of manganese in plants. In: Graham R.D., Hannam R.J., Uren N.C. (eds.) Manganese in Soils and Plants. Dordrecht: Kluwer Academic Publishers, p. 125-137.

Bussler W. (1981). Physiological functions and utilization of copper. In: Loneragan J.F., Robson A.D., Graham R.D. (eds) Copper in Soils and Plants. New York: Academic Press, p. 213-234.

Fox T.T. and M.L. Guerimot (1998). Molecular biology of cation transport in plants. Anmu. Rev. Plant physiol. Plant Mol. Biol., 49: 669-696. 
Gamal El-Din Karima M. (2005). Physiological response of fenugreek plant to heat hardening and zinc. Egypt. J. Appli. Sci., 20(6B): 400-411.

Gardner F.P., Pearce R.B. and R.L. Michell (1985). Physiology of crop plant. lowa State Univ. Press Ames. lowa. USA.

Gomez K.N. and A.A. Gomez (1984). Statistical procedures for agricultural research. John Wiley and Sons, New York, $2^{\text {nd }}$ ed.

Hageman R.H., F.E. Below, and Y.P. Abrol (1990). Nitrogen in Higher Plants. Taunton, England: Research Studies. p 313.

Hewitt E.J. and B.A. Notton (1980). Structure and properties of higher plant nitrate reductase especially Spinacia oleracea. In: Hewitt E.J., Cutting C.V. (eds). Nitrogen Assimilation of plants, Academic Press, London, p 227-244.

Huber S.C., T. Sugiyama and R.S. Alberte (1989). Photosynthetic Determinants of Growth in Maize Plants: Effects of Nitrogen Nutrition on Growth, Carbon Fixation and Photochemical Features. Plant Cell Physiol, 30:1063-1072.

Jackson M.L. (1973). Soil Chemical Analysis. Prentice Hall of India, Private Limited, New Delhi.

Jacobs B.D. and C.J. Pearson (1992). Pre-flowering Growth and Development of the Inflorescences of Maize: I. Primordia production and apical mode volume. J. Exp. Bot., 1992 43: 557-563.

Jeong J. and M.L. Guerinot (2008). Biofortified and bioavailable: the gold standard for plant-based diets. PNAS 6, 1777-1778.

Kumar B. and V.P. Singh (1997). Zinc status of rice plants as influenced by different levels and methods of zinc application. J. Soils and Crops, 7: 105-108.

Lerer M. and A. Bar-Akiva (1976). Nitrogen constituents in manganesedeficient lemon leaves. Physiol. Plant, 38: 13-18.

Lichtenthaler H.K. and A.R. Wellbum (1985). Determination of total carotenoids and chlorophylls A and B of leaf in Different Solvents. Biol. Soc. Trans , 11: 591-592.

Maischner H. (2002). Mineral nutrition of higher plants (2nd ed.). San Diogo, CA: Academic press.

Manian K., N. Natarajaratnam, P. Ramasamy and K. Mohanasundaram (1987). Senescence and its role in soybean productivity. J. Agron. Crop Sci., 159: 202-205.

Manoharan M.L., G. Kathiresan and A. Arokiaraj (2001). Zinc enriched presumed increase rice yield. The Hindu-Business/Science, Dt. April $5^{\text {th }}$.

Marschner H. (1995). Mineral nutrition of higher plant, Academic Press. New York.

Martignone R.A., J.J. Guiamet and F. Nakayama (1987). Nitrogen partitioning and leaf senescence in soybean as related to nitrogen supply. Field Crops Res., 17: 17-24.

Mayer J.E., W.H. Pfeiffer and P. Beyer (2008). Biofortified crops to alleviate micronutrient malnutrition. Curr. Opin. Plant Biol., 11:166-170.

Michael G. and H. Beringer (1980). Physiological aspects of crop productivity. $15^{\text {th }}$ Colloquium of the International Potash Institute, Berne, Switzerland, p 85.

Ness P.J. and H.W. Woolhouse (1980). RNA synthesis phaseolus chloroplasts. I. Ribonucleic acid synthesis and senescing leaves. J. WXP. Bot., 31: 223-233. 
Farouk, S.

Nobel P.S., L. Zaragoza and W. Smith (1975). Relation between mesophyll surface area, photosynthetic rate, and illumination level during development for leaves of Plectranthus parviflorus Henckel. Plant Physiol., 55:1067-1070.

Rao U.K., K.B. Reddy and B.R. Reddy (2001). Effect of sulphuric acid on control of lime induced iron chlorosis in groundnut. Indian J. Plant physiology, 3: 317-319.

Sadasivam S. and A. Manickam (1996). Biochemical Methods, Second Eddition, New Age International. India.

Sage R.F. and R.K. Monson (1999). C4 Plant Biology. Academic Press, London, UK.

Seadh S.E., M.I. EL-Abady, A.M. EL-Ghamry and S. Farouk (2009). Influence of micronutrients foliar application and nitrogen fertilization on wheat yield and quality of grain and seed. J. Biological Science, 9 (8): $851-$ 858.

Sienkiewicz-Cholewa U. (2008). Effect of foliar and soil application of copper on the level and quality of winter rapeseed yields. J. Elementol., 13(4): 615-623.

Singh B.K. and C.F. Jenner (1984). Factors Controlling Endosperm Cell Number and Grain Dry Weight in Wheat: Effects of Shading on Intact Plants and of Variation in Nutritional Supply to Detached, Cultured Ears Aust J Plant Physiol., 11: 151-163.

Sugiharto B. and T. Sugiyama (1992). Effects of Nitrate and Ammonium on Gene Expression of Phosphoenolpyruvate Carboxylase and Nitrogen Metabolism in Maize Leaf Tissue during Recovery from Nitrogen Stress. Plant Physiol., 1992 98: 1403-1408.

Swank J.C., F.E. Below, R.J. Lambert and R.H. Hageman (1982). Interaction of Carbon and Nitrogen Metabolism in the Productivity of Maize. Plant Physiol., 70: 1185-1190.

Terry N. and J. Abadia (1986). Function of iron in chloroplasts. J. Plant Nutr., 9: 609-646.

Thomas S.M., G.N. Thorne and H. Pearman (1978). Effect of Nitrogen on Growth, Yield and Photorespiratory Activity in Spring Wheat Ann Bot., 42: 827-837.

Tobbal Y.F.M. (2006). Physiological studies on the effect of some nutrients and growth regulators on plant growth and metabolism. Ph.D. Thesis, Fac. Sci. Al-Azhar Univ.

Tsai C.Y., D.M. Huber and H.L. Warren (1978). Relationship of the Kernel Sink for N to Maize Productivity. Crop Sci., 18: 399-404.

Tsai C.Y., D.M. Huber and H.L. Warren (1980). A Proposed Role of Zein and Glutelin as N Sinks in Maize Plant Physiol., 66: 330-333.

Walker C.D. and J. Webb (1981). Copper in plants: Forms and behaviour. In: Loneragan J.F., Robson A.D., Graham R.D. (eds). Copper in Soils and Plants. New York: Academic Press, p 198-212.

Wang F.H., J.S. Zhao and H.P. Liu (1995). The histological study on winter wheat varieties with different yield potential. Acta Agron Sin 21: 244 247. (n Chines e wit $\mathrm{h}$ English abstract).

Wang Y., S.S. Li, A.F. Li, X.B. Li, H.G. Wang and Q.Q. Li (2000). Evaluation of lodging resistance and relation and path analysis of lodging resistance traits in wheat. Acta Bot Boreali-Occidentalia Sin, 20: 79-85. (n Chinese with English abstract). 
Welch R.M. and R.D. Graham (2004). Breeding for micronutrients in staple food crops from a human nutrition perspective. J Exp Bot., 55(396): 353-364.

WHO (2007) Micronutrient deficiency: iron deficiency anaemia. Geneva: WHO, available from http://www.who.int/nutrition /topics/ida/.

Wojnarowiez C., P. Jacquard, R.S. Devaux, C. Sangwan and C. Clément (2002). Influence of copper sulfate on anther culture in barley (Hordeum vulgare L.). Plant Sci., 162:843-847.

Zhang S.X., X.B. Wang and K. Jin (2001). Effect of different $N$ and $P$ levels on availability of zinc, copper, manganese and iron under arid conditions. Plant Nutr. Fert. Sci., 7: 391-396.

Zhu C.F., S. Naqvi, S. Gomez-Galera, A.M. Pelacho, C.T. Teresa and P. Christou (2007). Transgenic strategies for the nutritional enhancement of plants. Trends Plant Sci., 12:1360-1385.

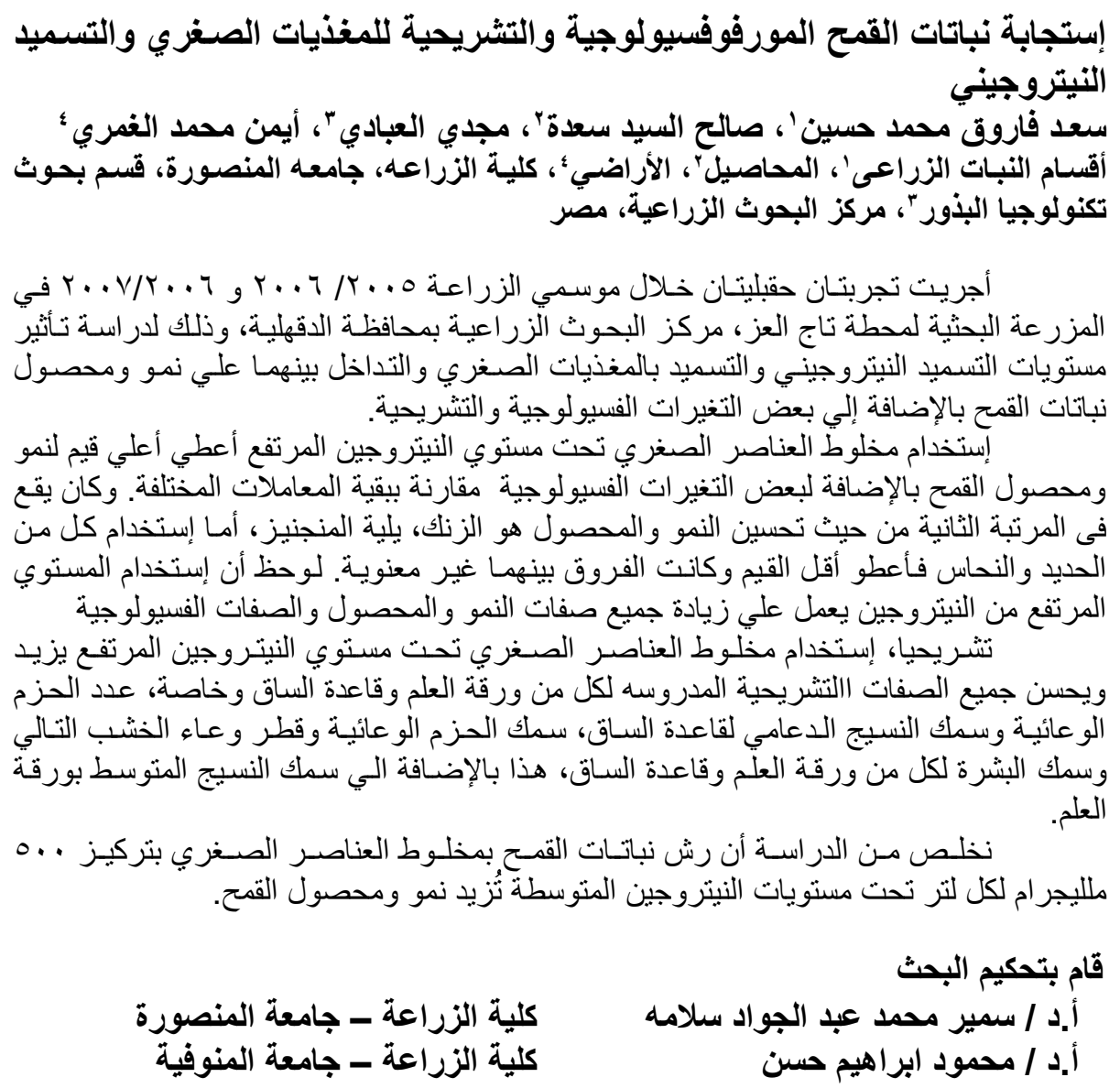

